Portland State University

PDXScholar

1974

\title{
An Analysis of the Interrelationship Between the Oregon School Law of 1922, the Press of Oregon, the Election of Walter Pierce and the Ku Klux Klan
}

Robin Huffman

Portland State University

Follow this and additional works at: https://pdxscholar.library.pdx.edu/open_access_etds

Part of the United States History Commons

Let us know how access to this document benefits you.

\section{Recommended Citation}

Huffman, Robin, "An Analysis of the Interrelationship Between the Oregon School Law of 1922, the Press of Oregon, the Election of Walter Pierce and the Ku Klux Klan" (1974). Dissertations and Theses. Paper 2043.

https://doi.org/10.15760/etd.2042

This Thesis is brought to you for free and open access. It has been accepted for inclusion in Dissertations and Theses by an authorized administrator of PDXScholar. Please contact us if we can make this document more accessible: pdxscholar@pdx.edu. 
AN ABSTRACT OF THE THESIS OF Robin Huffman for the Master of Arts in History presented July 9, 1974.

Title: An Analysis of the Interrelationship between the Oregon School Law of 1922, the Press of Oregon, the Election of Walter Pierce and the $\mathrm{Ku} \mathrm{KIUx} \mathrm{KIan.}$

APPROVED BY MEMBERS OF THE THESIS COMMITTEE:

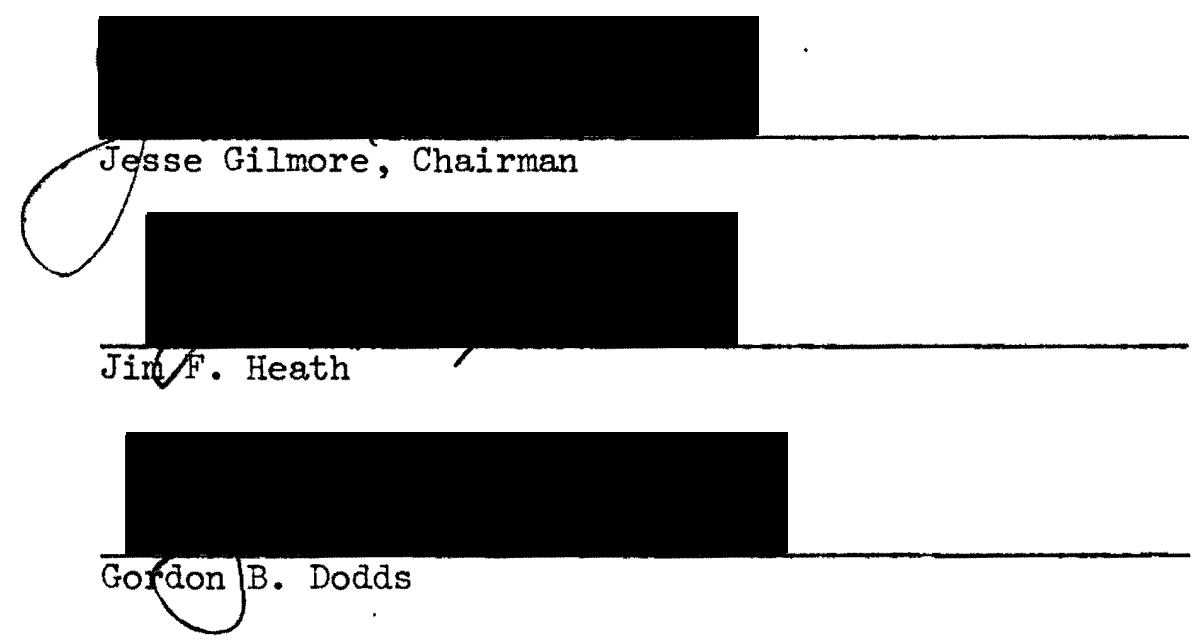

Oregon in 1922 was the scene of significant Ku KIux KIan activity. This thesis examines the interrelationship of the Klan, the press of Oregon, the gubernatorial race of that year and the passage of the Compulsory School Act. In addition, one chapter covers the ultimate fate of the Compulsory School Act in the courts. Specific material in this thesis is derived principally from newspapers and periodicals of the time, although general sources on the Ku Klux Klan were utilized for the broader discussions of the situations.

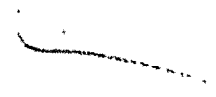


The existence of the Ku Klux Klan in Oregon in 1922 directly affected both the passage of the Compulsory School Act and the election of Walter Pierce. The roles of the state's newspapers were mixed. Two were quite outspoken on the issues of the Klan and the Compulsory School Act, while most took less forthright stands. It was in the United States Supreme Court, however, that the final decision on the Compulsory School Act was made. 
AN ANALYSIS OF THE INTERRELATIONSHIP BETWEEN THE OREGON

SCHOOL LAW OF 1922 , THE PRESS OF OREGON,

THE ELECTION OF WALTER PIERCE AND

THE KU KLUX K工AN

by

ROBIN HUFFMAN

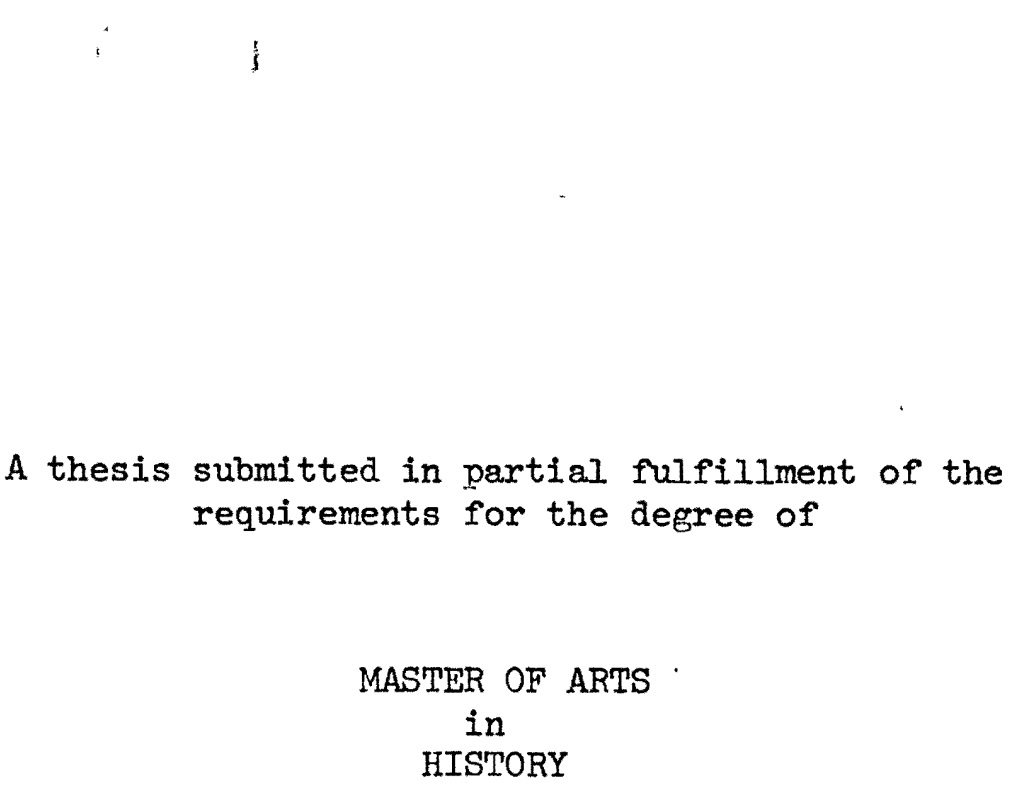

Portland State University 1974 
TO THE OFFICE OF GRADUATE STUDIES AND RESEARCH:

The members of the Committee approve the thesis of

Robin Huffman presented July 9, 1974.

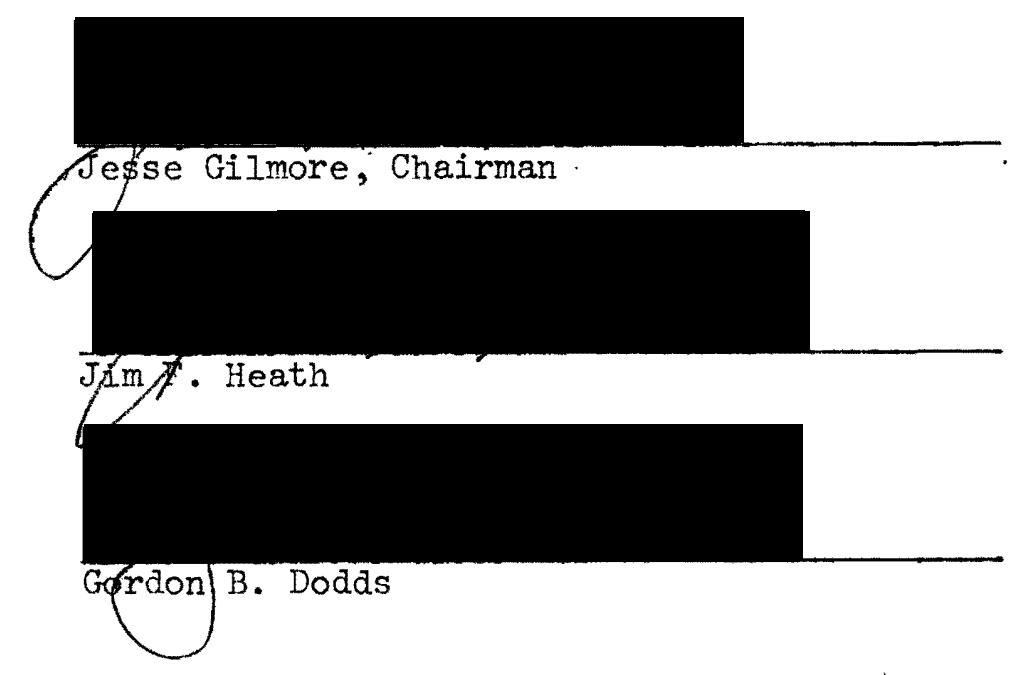

APPROVED:

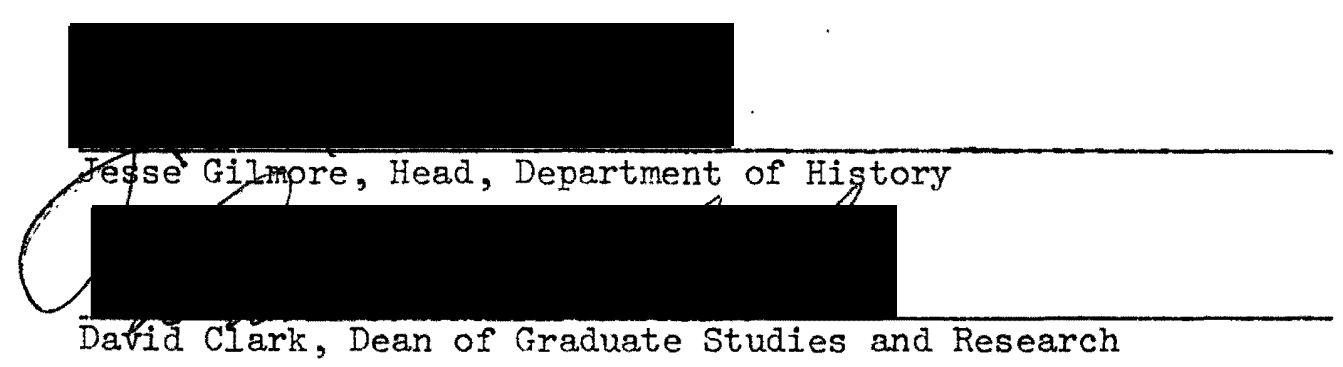

July 9,1974 


\section{TABLE OF CONTENTS}

\section{PAGE}

\section{CHAPTER}

I BACKGROUND OF THE KLAN IN OREGON 1

II THE GOVERIOR'S RACE 12

III THE PUBLISHED WAR $\quad 29$

IV THE COURT BATTLE OVER THE COMPULSORY SCHOOL ACT 48

$\begin{array}{lll}\text { V CONCLUSION } & 57\end{array}$

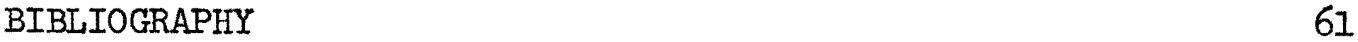




\section{CHAPTER I}

BACKGROUND OF THE KIAN IN OREGON

The decadè following World War One saw a resurgence of Ku KIUx Klan activity in many states. Patriotic fervor remaining from the war combined with a growing distruct of foreign and liberal ideas to produce this phenomenon. Irving Werstein has written, "In such an atmosphere of intolerance it was not strange that the $\mathrm{Ku} \mathrm{Klux} \mathrm{Kl}$ an had a rebirth." 1 The Deep South of course was affected by this movement, being the home of the original post-Civil War Klan. Also, however, such distant states as Colorado and Oregon felt the stirrings of the revitalized Klan.

Lipset and Raab in The Politics of Unreason: Right-Wing Extremism in America 1790-1970 note that the Klan in the 1920's found its strongest pockets of support to be in new population areas of industrialized cities. The people in these areas, having come from rural America, developed feelings of loss and displacement in their lives. ${ }^{2}$ Such was the case in Oregon, for the major center of KIan strength was Portland, even though the Klan remained active in other parts of the state as well.

${ }^{1}$ Irving Werstein, The Shatter Decade (New York, 1970), p. 29.

${ }^{2}$ Seymour Martin Lipset and Earl Raab, The Politics of Unreason: Right-Wing Extremism in America 1790-1970 (New York, 1970), pp. 121-123. 
On the surface Oregon was an especially strange state for fertile Klan activity. Eighty-five percent of Oregon's population in 1920 were "native white," that is, both Caucasian and American-born; five percent were Oriental; less than eight percent were white Catholics; and only one and one half percent were illiterate. 3 However, an analysis of the background of the eighty-five percent American-born Caucasians reveals the reasons for solid Klan support in the state. Because of great immigration to Oregon from the Mississippi Valley, the seeds of intolerance were present in the state during the $1920^{\prime} \mathrm{s}$. John M. Mecklin in The Ku Klux Klan wrote:

They (Oregonians) belong, therefore, to that old American stock from which throughout the Middle West the anti-Catholic and native American movements, the Know-Nothingism and the A.P.A., drew their chief support. Their mental attitudes, in spite of their freer western life, are not essentially different from those of the people of Texas, Missouri, Kansas, and Indiana. The anti-Catholic tradition has been generally familiar to them from childhood.

Mecklin also cited the remote aspect of many Oregon towns and villages as beneficial to Klan organization, for communication with the more cosmopolitan areas of the country was apparently minimal. 5

Outlook magazine underscored the swell and direction of Klan activity in Oregon. Special correspondent Waldo Roberts correctly observed, "Without enough Negroes to man a Pullman car, without any

\footnotetext{
3John Moffatt Mecklin, The Ku Klux Klan (New York, 1924), p. 44. ${ }^{4}$ Mecklin, p. 45.

5 Mecklin, p. 45.
} 
alien problem worthy of the name, anti-Catholicism remained as the only possible leg upon which the Klan could stand." 6 (Roberts did overlook the Japanese minority in the state, although the drive to deny Orientals land ownership or control rights was an issue in the 1922 gubernatorial nominations races.)

The Klan's first foothold was in the southern part of the state. Luther I. Powell of Shreveport, Louisiana organized a klavern in Medford early in 1921. Portland, however, was the economic and social center of the state; it was to that city that the Klan next turned its attention. The first organizational effort in Portland met with utter failure. Klansman Bragg Calloway, dispatched from Atlanta, disobeyed his headquarter's instructions to avoid the press. Calloway talked with eager reporters about his mission building Portland membership. Amid the resultant publicity he was immediately withdrawn. ${ }^{7}$

Calloway was replaced by Iuther Powell. After the latter's successes in Southern Oregon, he was the logical choice to replace the verbose Calloway. Powell met with great, albeit quieter, success. Recruitment was accomplished through mailing lists compiled from directories of Portland's societies and clubs. ${ }^{8}$

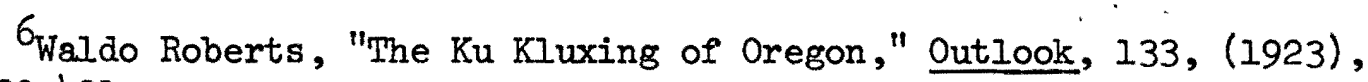
pp. $490-491$.

7 Kenneth T. Jackson, The Ku Klux Klan in the City, 1915-1930 (New York, 1967), pp. 196-197.

$8_{\text {Jackson, pp. 196-197. }}$ 
In the midst of Powell's organizational drive, Republican

Governor Ben Olcott was asked the extent of Klan efforts in Oregon.

With words that would surely return to haunt him, 0lcott replied:

Because of the wholesome conditions in Oregon, with little discontent and a satisfied people, the $\mathrm{Ku} \mathrm{K} I \mathrm{ux} \mathrm{Kl}$ an, although endeavoring to invade the state, has made little or no progress and $I$ am informed it is now folding its tent like the Arabs and as silently stealing away. The Klan has been taken lightly here, and because of the fact that it has made practically no impression on our people or our institutions, the executive office of this state has deemed action or any particular comment unnecessary. (September 22, 1921. $)^{9}$

By the end of 1921, however, the Klan had emerged as a viable Oregon institution with the greatest numerical success in the Portland metropolitan area. 10

The extent of KIan membership in Oregon has always been debated; mecause mbership lists were secret, it has never been pinned to a
specific figure. David Chalmers in Hooded Americanism estimates that
$\mathrm{K}$ lan membership in Oregon in the spring of 1922 was fourteen thousand with half of this number in the Portland area. This represented around two percent of the state's adult population. 11 (The spring of 1922 was crucial for the Klan, for the primaries occurred in May, and the Klan evidenced interest in races ranging from local school board sorties to the governorship of the state.)

qJackson, p. 197.

Id Jackson, p. 198.

11 David Chalmers, Hooded Americanism (Garden City, New York, 1965), p. 88 . 
Ultimately, Klan numbers in Oregon climbed to approximately twenty-five thousand members. ${ }^{12}$ The Klan's membership was greatest after the successful drives for Walter Pierce and the Compulsory School Act, but this peak was soon lost as members forsook the Oregon Klan as it became embroiled in internal squabblings.

Before this decline, however, the Invisible Empire in Oregon found its greatest success in anti-Catholicism. Mecklin wrote of the Klan in 1924 that, "A canvass of motives for joining the Klan indicates that anti-Catholicism takes precedence over all others."13

Catholicism in America has traditionally rejected the public school system in favor of its own extensive educational plan. It is in this rejection of public schools that Klansmen in Oregon found their largest issue. Stanley Frost, a contemporary apologist for the Klan, spoke of the importance of public schools at the national level:

One of the strongest motives in drawing men into the $\mathrm{Klan}$, or perhaps it would be more correct to say that one of the strongest desires now in the minds of the Klansmen, is for reform of the public schools. 14

Klansmen, according to Frost in his book The Challenge of the Ku Klux Klan, held almost a conspiracy theory that the nation's public schools were deliberately neglecting to teach the values of

12Chalmers, p. 88.

13 Mecklin, p. 38 .

${ }^{14}$ Stanley Frost, The Challenge of the Ku Klux Klan (New York, 1925), p. 169. 
citizenship. "They (the Klansmen) blame the Catholics," asserted Frost, for the following three reasons: First of all, some Catholics supported laws outlawing Bible teaching in public schools. (This complaint probably reflects the Southern fundamentalist orientation of the Klan.) Secondly, no adequate appropriations were given to projects for teaching the value of citizenship. Finally, the Roman Catholic teachers in public schools allegedly taught poorly on purpose. 15

That Frost was indeed an apologist for the Klan is easily established. After characterizing most Klansmen as "good, solid, middle-class citizens," he added:

But it is always reform of one kind or another, and however warped or misdirected, it is almost always aimed at some real wrong or abuse. It may err in ascribing the evils to Catholics, Jews, or aliens, but the evils themselves are actual enough. 16

Whatever evils the Klan went questing for, anti-Catholicism always was a strong organizational tool. Chalmers writes of the usual routine:

First, under the auspices of some Protestant church, an 'escaped nun' would tell of her ordeal. Next, the Klan's anti-Catholic and patriotic pamphlets would be slipped into cars and under doors. Then, a fire-branding evangelist or Klan lecturer would whip up feeling against the 'Roman Octopus which has taken over control of the nation's capital. "17

\footnotetext{
I5Frost, pp. 169-170.

$16_{\text {Frost ; pp. } 2,170 .}$

$17_{\text {Chalmers, p. } 86 .}$
} 
Once organized in Oregon, the Klan worked most effectively with the Federation of Patriotic Societies. The latter group was incorporated in Oregon during World War One as an "instrument to counteract the strength of corporate power in Oregon. "18 The Federation had begun informally in 1914 as a few interested citizens began "indorsing candidates to overcome the alleged preponderance of the Catholic church in Portland politics."19 By the 1920's the Federation had earned a reputation for fighting the excesses of some of Oregon's public utility companies. Membership in the Federation included the Loyal Orange, the Odd Fellows, the Masons, and the Knights of Pythias plus thirteen other, like-minded organizations. 20

The link between the Federation and the Klan was a definite one. Although the Klan never became a formal member of the Federation, the Grand Dragon of the Ku KIux Klan in Oregon, Fred Gifford, was elected director of the Federation. Kenneth T. Jackson in the Ku Klux Klan in the City points out that the overlap in membership between the KIan and the recognized members of the Federation was great enough to accomplish this election. 21

The Klan's preoccupation with Catholicism and public schools, combined with its alliance with such groups as the Federation of

18 Chalmers, p. 85.

${ }^{19}$ Oregon Voter, September 16,1922, p. 5.

20 Jackson, p. 203.

21Jackson, p. 205. 
Patriotic Societies, gave it both an issue and a basis of support in moving into the political arena. The spring of 1922 saw a new interest by the Klan in Oregon politics at all levels. It was the Compulsory School Act, however, which gave the Klan its most stunning success.

Basically, the Compulsory School Act proposed that Section 5259, Oregon laws, be amended to require that all children between the ages of eight and sixteen attend public school; that a parent's or guardian's failure to send his charge to public school constitute a separate misdemeanor for each day the child failed to appear; and that the county school superintendent be called upon to oversee the law. Certain exceptions were allowed: e.g., the physically handicapped, those children living great distances from public schools, and those children who had completed eighth grade. 22

Obviously, the effect of the Compulsory School Act would be to outlaw private and parochial schools, force attendance in public schools, and strike well-aimed blows at both exclusive private schools and the entire system of religious schools in Oregon.

Jackson underscores the Klan technique of changing the basic issue from an attempt to outlaw Catholic schools (which the Compulsory School Act actually did) to an attempt to prevent Catholics from over-running public schools. 23 Examples used by the Klan included ${ }^{22}$ Compulsory School Act as cited in 45 Supreme Court Reporter 572.
23 Jackson, p. 205 . 
pictures of Catholic nuns teaching in "tax-supported institutions." In his notes Jackson affirms that this was occasionally true, for some Catholic communities such as St. Paul did allow nuns to teach in the public schools. 24

While the $\mathrm{Ku} \mathrm{KIUx} \mathrm{Klan} \mathrm{was} \mathrm{one} \mathrm{of} \mathrm{the} \mathrm{hardiest} \mathrm{supporters} \mathrm{of}$ the Compulsory School Act, the Scottish Rite Masons were the named sponsors, Masonry, however, was split upon the issue. Mecklin, writing in 1924, stated, "Although this measure was proposed by a Scottish Rite Mason it seems to have been drafted by Klansmen and put through by their support. Leading Masons have condemned it."25 George C. Brown, Grand Master of the Masons in Oregon, flatly claimed no connection between the initiative measure and his organization. 26 Masons from California and Massachusetts decried the $\mathrm{Klan} .27$ The fact remains, however, that significant support for the Compulsory School Act was garnered, albeit unofficially, from Masons in Oregon. Petitions were distributed to the lodges, and many advertisements were paid for by the Scottish Rite. 28 The Klan also sponsored

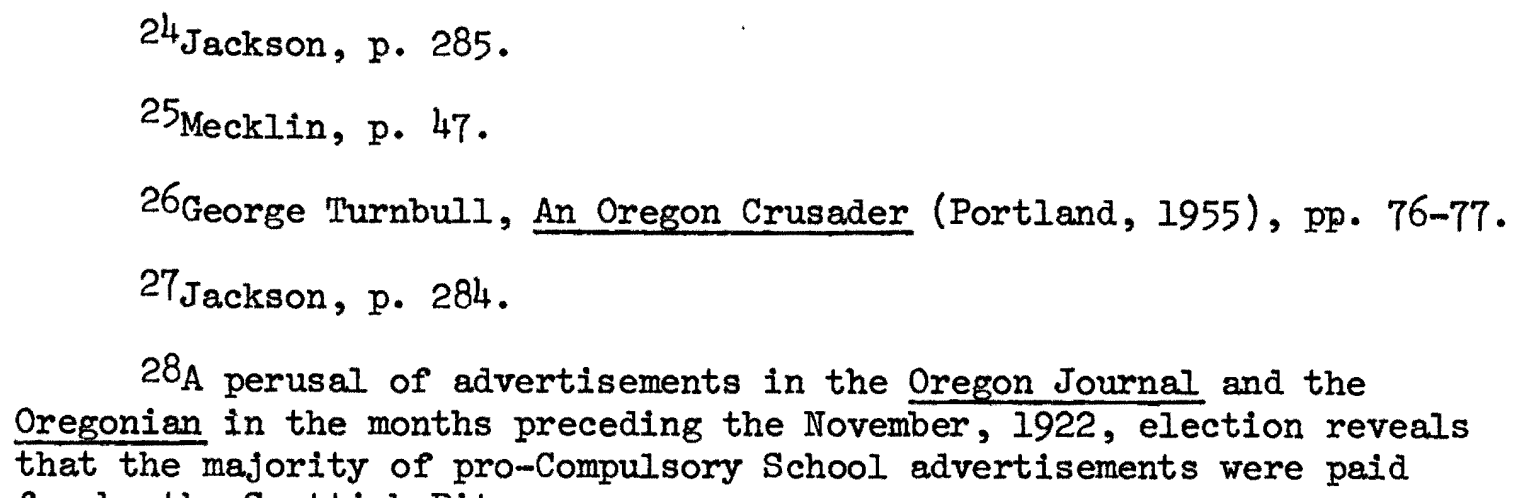
Oregonian in the months preceding the November, 1922, election reveals that the majority of pro-Compulsory School advertisements were paid for by the Scottish Rite. 
advertisements, dishonestly alleging them to be paid for by a nonexistent Catholic Defense League. 29

One wonders, however, if the passage of years since those heated times in the 1920's has in some way warped our perspective. Those who have written most voluminously of the uproar of the Compulsory School Act are precisely those whose own interests lay in exposing its insidiousness. Father Lawrence Saàfeld, a Catholic historian whose unpublished master's thesis Forces of Prejudice in Oregon 1920-1925 has been used by both Jackson and Chalmers, falls into this category.

The liberal Eastern press of the day saw in the Oregon experience both a threat and interesting copy. Oregon's own press, as will be demonstrated in the next chapters, was in most instances reticent to deal with the Klan. Did this reticence reflect, as the Oregon Journal claimed, an inability to deal with "the religio-racial hate now raging in this town?" 30 Or was it simply a reflection of the fact that later historians have read much more into the role of the KIan and the threat of its political activities than actually existed? These questions must be raised so that the reader realizes the lack of impartiality of existing sources.

The KIan campaigns for the Compulsory School Act and for an acceptable gubernatorial candidate will be discussed in the next

${ }^{29}$ Chalmers, p. 89.

${ }^{30}$ Oregon Journal, May $16,1922$. 
chapters. Not only was the Ku Klux Klan in Oregon organized and equipped with the proper psychology for supporting the anti-Catholic Compulsory School Act, it was willing to embroil the state in a vicious political race by steadfastly opposing Republican incumbent Ben Olcott. As the New York Times put it, "The School Bill was the most upsetting factor in the history of Oregon since the agitation over slavery." 31 Governor Olcott must have agreed. 
CHAPTER II

THE GOVERNOR'S RACE

In 1922 Republican Governor Ben Olcott was running for his first election to the post he had held since the death of Governor Withycombe. During the winter before the May primary, his chances looked healthy; by the following November Olcott had lost the position by over thirty thousand votes. ${ }^{1}$ In less than one year's time the election had swung neatly to Walter Pierce, who was both a Democrat in a Republican state and the first man from Easterm Oregon to be elected to the governorship.

To be sure, Olcott's record at the polls was not strong. He had advanced more by the timely deaths of his predecessors than by actual votes cast. He was originally appointed Secretary of State when the incumbent Frank W. Benson died on April 17, 1911; after re-elections in the years 1912 and 1916, 01cott succeeded James Withycombe as Governor after the latter's death of March 3, $1919 .{ }^{2}$ Still, Olcott was popular with the people of Oregon. The state's press for the most part supported him, and most Oregonians conceded

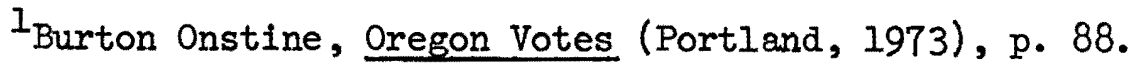
${ }^{2}$ Charles Henry Carey, History of Oregon, Volume I (Portland, 1922), p. 900 . 
that the Oregon Voter's observation was correct: Ben Olcott was a "Man of Principle." 3

Olcott set out to gain the governorship in his own right in 1922. The field, particularly on the Republican side of the primary ticket was crowded by seven entries, but the real race was between Olcott and Marshfield State Senator Charles Hall.

The Oregon Voter, a weekly published to inform Oregonians of political issues, provided the best comparison of the Republican primary candidates in its issue of April 22, 1922. Each candidate's program was printed; but because each was limited to less than one hundred words the ideas expressed were at best general.

Some candidates really did not count. Phillip Withycombe of Yambill, brother of the deceased governor whom Olcott had replaced, withdrew at such a late date that his name remained on the ballot. George White of Salem filed a campaign statement that omitted mention of even a single specific issue. J. D. Lee of Portland preached economy and "Fairness to auto owners." Louis Bean of Eugene favored open government, probably a gentle slam at the Ku Klux Klan, but did agree with that organization on one of 1922's more emotional issues, that of denying land ownership or control rights to Orientals. 4 The two strongest Olcott challengers were I. I. Patterson of Salem and Charles Hall of Marshfield. Next to Olcott, these two men

3 The Oregon Voter, October 28,1922, p. 3.

${ }^{4}$ Oregon Voter, April 22, 1922, pp. 6-8. 
had the best chances in April of 1922 of capturing the nomination. Patterson was popular in an extremely tax-conscious year because of his call to lower all state salaries to a pre-world war level. 5

Hall, however, represented the greatest challenge to Olcott. The Marshfield State Senator was for economy in government, denial of land ownership rights to Japanese, and the Compulsory School Act which would insure the "teaching of pure Americanism to all pupils." 6

That $\mathrm{Hall}$ was the first choice of the Klan and related interest groups is little disputed. His early strong support for the Compulsory School Act won him the affection of the Klan, but their support was tempered by their estimation of Fall's chances against Olcott. The Oregon Voter of April 1, 1922 reported that whereas Olcott "has the big lead although there are localities and interests with which he is exceedingly weak," Hall was in danger of losing the support of the Klan and the Federation of Patriotic Societies. These groups apparently feared "picking a loser."7

Obviously, they overcame their fear. The Literary Digest had claimed that Hall was openly backed by the Klan; few wanted to dispute the allegation. ${ }^{8} \mathrm{M}$. Paul Holsinger, writing in the Pacific Historical

5 Ibid.

6 Ibid.

TOregon Voter, April 1, 1922, p. 3.

8"The Ku Klux Klan in Politics" (anon. article), Literary Digest, IXXXII (June 10, 1922), p. 15. 
Review, has echoed this assessment. 9 The Oregon Voter also realized the ties between Hall and the Klan. Writing a summary of and editorial on Hall's voting record, which included strong support for roads, an active history of introducing "constructive" legislation and one hundred ninety-one missed roll call votes, making Hall "one of the champion missers," the Voter concluded: "It is to be regretted that as a candidate he permitted himself to become burdened with the support of a secret political organization on an issue of religious fanaticism." 10

Olcott was the choice of the Oregon Voter. 11 Throughout the primary he had maintained support "for an absolutely impartial government for all the people." 12 On May 10 the Portland Telegram also announced its support for 0lcott. Again, the character of the man was stressed. "The nomination of Governor Olcott would, of course, mean his election. The people would know in advance who would be the real governor, for Governor Olcott has always shown himself to be his own man."13

9M. Paul Holsinger, "The Oregon School Bill Controversy, 19221925," Pacific Historical Review, XXXVI (October, 1968), p. 331.

${ }^{10}$ Oregon Voter, May 6, 1922 , pp. 3-5.

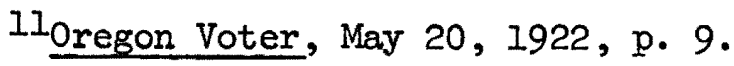

120regon Voter, April 22, 1922, pp. 6-8.

13Portland Telegram, May 10, 1922. 
Olcott himself added the final intense touch to a political campaign which the New York Times called, "The bitterest and closest political campaign in Oregon's history."14 On the Saturday before Thursday's primary election, Ben Olcott issued a proclamation condemning the participation of secret societies in Oregon politics. Strongly calling for an end to religious bigotry, Olcott pledged to uphold the state law which encouraged open meetings with a minimum of secret activities.

By Sunday, May 14, the Klan officials had responded to the Olcott Proclamation by insinuating that the governor was making a play for votes. 16 olcott then reiterated that he had never "Sought, asked for, or received the secret indorsement of any clan, society or organization." The Klan accused 0lcott of being the one to introduce religious controversy into the campaign. Fred Gifford, Exalted Cyclops of Luther Powell KIan No. 1, claimed that the only qualifications to gain the support of the Klan were "loyalty to the free public schools, loyalty to the government of the United States and the question of anti-alien land bills." 17

The whole uproar was too much for the Oregon Journal. In an editorial entitled "Portland's Bad Blood," the newspaper hit at the

${ }^{14}$ Literary Digest, June 10, 1922, p. 15.

${ }^{15}$ Portland Telegram, May 13, 1922.

16 Oregon Journal, May 14, 1922.

17 Oregon Journal, May 16, 1922. 
underlying feeling of hatred which had breathed fire into the governor's race. After declaring that the religious strife in Portland was reaching dangerous levels, the Oregon Journal revealed that it had experimented with printing a few letters from all sides of the controversy in the hope that the "discussion would go forward within reasonable limits and in a spirit of moderation." The Journal alleged that its "experiment" had failed, that it had been inundated with letters the "spirit of which was amazing and a sufficient proof of the folly of letting the debate continue."

The Journal gave two reasons, therefore, for not printing any letters at all. Firstly, it would be impossible to print all, so none would be printed. Secondly, "The Journal will not allow its columns to be used to throw more brands into the fires of the religioracial hate now raging in this town. "18

Having assumed this stance, the Oregon Journal dutifully reported only the facts of the news regarding the $\mathrm{Kl}$ an, the Compulsory School Act and the governor's race without exercising its perogatives to deal editorially with the emotions which had bred the situation in the first place.

If the Republican side of the ballot was heated, the Democrats were only slightly calmer. Four candidates announced for the gubernatorial nomination, three of them serious and one, Will E. Purdy of

${ }^{18}$ Ibid. 
Salem, scarcely to be believed. Running on the slogan of "No apology for high taxes; I was not representing the electors," Purdy held that the "kick must be taken out from moonshine and we must knock the hell out of those who draw state money without earning it." 19 The Oregon Voter conceded that Will Purdy. was "impossible."20

Of the three remaining candidates, Arthur F. Flegel had the least chance, having denounced both the concept of a Compulsory School Act (then only in its initiative stage) and the $\mathrm{Ku} K I \mathrm{Kx} \mathrm{KIan} .{ }^{2 l}$ The Portland Telegram correctly observed that the real race was between Walter Pierce of LaGrande and Harvey Starkweather of Milwaukie. 22 Starkweather, whose slogan was the cryptic "Save the home," was opposed to land ownership by Orientals. ${ }^{23}$ On May 20, 1922 he garnered the less than enthusiastic support of the Oregon Voter for the Democratic nomination. 24

Around Walter Pierce swirled the most controversy. As early as April 15, the Oregon Voter had lambasted Pierce for his failure to resign from the nonpartisan Tax Investigation Commission. The Voter

19 Oregon Voter, April 22, 1922, p. 8. 20 Oregon Voter, May 20, 1922, p. 41.

21 Robert E. Burton, Democrats of Oregon: The Pattern of Minority Politics 1900-1956 (Eugene, 1970), p. 47.

22 Portland Telegram, April 25, 1922.

23 Oregon Voter, April 22, 1922, p. 8.

24 Oregon Voter, May 20, 1922, p. 41. 
held that Pierce was using a state-sponsored comittee to boost his own campaign for governor, concluding, "Walter is a law unto himself."25

Nor was the Voter more taken with Pierce's legislative record. Conceding only that he had a "genuine interest in all welfare legislation," it saw him as one who "excelled in sob eloquence" and "invariably favored the so-called 'popular side' of every issue." 26

Pierce had as his main issue cutting taxes. However, W. Paul Holsinger rightly points out that Pierce was a decided underdog in a Republican state; thus, although never a Klansman himself, he eventually welcomed the support of the Klan as he came out "flatfootedly" for the Compulsory School Act. 27

Pierce as early as April 22 had declared, "I will protect the free public school and institutions of higher learning." 28 This stand was acceptable to the Klan and the Federation of Patriotic Societies, but before the primary the attention of these groups went to the Republican side of the ballot.

The May 17 election for the Republican gubernatorial nominee proved to be one of the closest in the state's history. Olcott's startling proclamation had reclaimed for the Republican side any attention the Democrats had been able to generate.

${ }^{25}$ Oregon Voter, April 15, 1922, pp. 12-13. ${ }^{26}$ Oregon Voter, May 13,1922, p. 8. 27 Holsinger, p. 331 . 28 Oregon Voter, April 22, 1922, p. 8. 
The Oregon Voter come out for Olcott and Starkweather. 29 The latter lost rather clearly to Walter Pierce; Olcott's victory over Hall was so narrow that the ensuing recount and court battles took two months to unravel.

The count as published by the Oregon Voter was as follows:

Democrats :

Pierce

Starkweather

15,144

Others

6,325

3,256

Republicans :

Olcott
Hall
Patterson
White
Others

43,032

42,511

13,019

10,156

$5,936^{30}$

The voter turnout was good, but not quite as heavy as the fall gubernatorial vote a few months later.

Holsinger accepts this count between Olcott and $\mathrm{Hall}$, al though the subsequent recount altered the tally slightly. Olcott lost, however, "nearly all the more populous counties." Obviously, this did not bode well for the November elections if Olcott persisted in being anti-KIan. 31

Olcott won a preliminary court battle when Marion County Circuit Court Judges G. G. Bingham and Percy Kelly ruled that although a small number of Olcott votes in a challenged precinct may have been illegally cast, the results of the entire precinct were valid. The

29 Oregon Voter, May 20, 1922, pp. 9, 41.

30 Oregon Voter, June 24,1922, p. 5.

$31_{\text {Holsinger, }}$. 331 . 
Hall contingent had claimed that of the fifteen votes cast in the Horeb precinct of Marion County, seven were invalid because they represented the votes of unregistered voters or of Democrats.

Other related protests filed by the Hall group alleged that voters had switched party registrations for fraudulent purposes or that some votes had been influenced unduly by Roman Catholic priests and thus illegally represented the voice of the Church.

Bingham responded to this latter charge by stating that such fraudulent influence must be established in individual cases, a well-nigh impossible task. 32

The actual recount of the Catholic precincts showed no irregularities. The Oregon Voter commented on the surprised reaction of Oregonians to the honest procedures used in these precincts:

Many honest Protestant people are sincerely shocked at the asscovery that no crooked work was revealed by the recount of the Olcott-Hall vote in the Catholic precincts of Marion County. The supposition was general in Protestant circles that fraud had been practiced. Now that it is demonstrated that the official count in these precincts was honest, many hitherto dissatisfied will become reconciled to the olcott nomination if finally substantiated. 33

When half of the fifty contested Marion County precincts had been counted, Hall was discouraged to discover that olcott had gained three votes.

32 Oregonian, August 1, 1922.

33 Oregon Voter, August 5, 1922, p. 11. 
After the recount was completed in Marion County, the court proceedings switched to Portland. Multnomah, Columbia, Clackamas and Washington counties all had precinet counts challenged by Hall. Meanwhile, the 0lcott attorneys threatened to prepare a counterpetition alleging undue influence at polling places by pro-Hall members of the Ku KIux Klan. 34

By the end of the week the net gain for Hall in Multnomah County was one vote, certainly not revealing the decisive mishandling of votes he had expected. Nor were things going better for him on the legal front. The judges were still insistent that fraud had to be proved in individual cases with specific charges. 35

The loudest cries of fraud, however, were yet to come. In Precinct 201 of Multnomah County the recount revealed that eighteen Olcott votes were omitted from the original tally, while sixteen Hall votes had been mysteriously added. Hall attorney W. S. U'Ren immediately announced that the recount drive would be dropped, not mentioning the shadowy vote in Precinct 201. U'Ren pointed out that a recount of over twenty thousand ballots had resulted in only a handful of changes. Thus, it was illogical for the Hall challenge to be carried any further.

${ }^{34}$ Oregonian, August 2, 1922.

350regonian, August 6, 1922. 
Precinct 201's chairman, William Emrich, was head of the local "law and order" league. "Among the members of the law and order league were men who were supposed to be active in the $K u K I u x K I a n . " 36$

The Oregon Voter had supported olcott in the recount battle from the start. It early had expressed fears that the recount tally would not be fair because errors did occur in almost all precincts. Thus, Hall challenged only those precincts with a heavy Olcott vote. Since individual candidates had to pay for their own recount battles, Hall was at a distinct advantage for he was rumored to have the financial support of the Klan. Olcott had no such organization to finance his fight. According to the Oregon Voter:

The net result of a partial recount, with the advantage all to the contesting candidate who is backed financially by a large organization, may be to wrest from 0lfott a nomination to which a complete recount would entitle him. ${ }^{31}$

Now, when the Hall forces stood accused of fraud, the Oregon Voter pointedly observed that absolutely no evidence of fraud had been found on the Olcott side of the ballot. 38

The Hall people responded in the next issue of the Oregon Voter. They denied that the recount had been suddenly dropped, holding that the end had been long before determined as precinct after challenged precinct showed none of the gross errors suspected by the Hall group.

36 Oregonian, August 10, 1922.

37 Oregon Voter, July 22, 1922, p. 3.

${ }^{38}$ Oregon Voter, August 19,1922, p. 8. 
The Oregon Voter upheld its comments of the previous week. The Multnomah County precinct in question, it noted, had revealed sufficient suspicion of fraud to warrant a grand jury investigation. 39 If Hall withdrew from contention for the Republican nomination after the revelations in Precinct 201, he all but threw his hat into the ring as an independent. A group calling itself the Public Defense League, comprised of anyone willing to contribute money to Hall's campaign, issued a statement intimating that the court process had denied Oregonians their true choice for the Republican nomination:

It may become necessary to consider whether an opportunity should not be offered the people of the state of Oregon to vote for that protestant candidate whom it has now become apparent was actually nominated by the bonafide republican voters of the state. $(\text { sic })^{40}$

The question of $\mathrm{Kl}$ an support for $\mathrm{Hall}$ as an independent was cleared by the subsequent announcement of August 18 by Fred Gifford. The Klan would not support an independent in the gubernatorial race. Gifford did not, however, announce whom the Klan would support, but given Olcott's outspoken attack on the Klan in his May Proclamation, Pierce was left as the Klan candidate by default. 41

Pierce also received the backing from groups other than the Klan. Robert $\mathrm{E}$. Burton in Democrats of Oregon: The Pattern of Minority

${ }^{39}$ Oregon Voter, August 26, 1922, p. 23.

40 Oregonian, August 10, 1922.

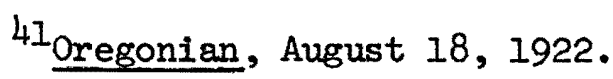


Politics 1900-1956 feels that the Federation of Patriotic Societies supported Pierce because of his stand opposing favortitism for special interests in Oregon politics. Likewise, small farmers were attracted to Pierce because of his anti-corporate interests position. Pierce also was an early supporter of the development of Pacific Northwest hydroelectric power, which was an increasingly popular stand. 42

The critical issue of Klan support for Pierce was apparently not resolved until the early days of September, 1922. Hall declared as an independent candidate for governor on September 10.43 Three days later, Walter Pierce made public a letter dated September 3 in which he came out "flatfootedly" in favor of the "so-called 'compulsory education' bill and with elaborate protestations of his pedigreed Protestantism," as the Oregon Voter put it. 44 Claiming that the secret societies of Oregon controlled an estimated forty thousand "canned" votes, the Voter queried, "Who will get the forty thousand votes?" 45

In light of Gifford's statement after the Hall recount fiasco, it was evident secret society support would go to Pierce.

The Compulsory School Act sponsors wanted to ensure Pierce's active, vocal participation in that battle. Therefore, even if

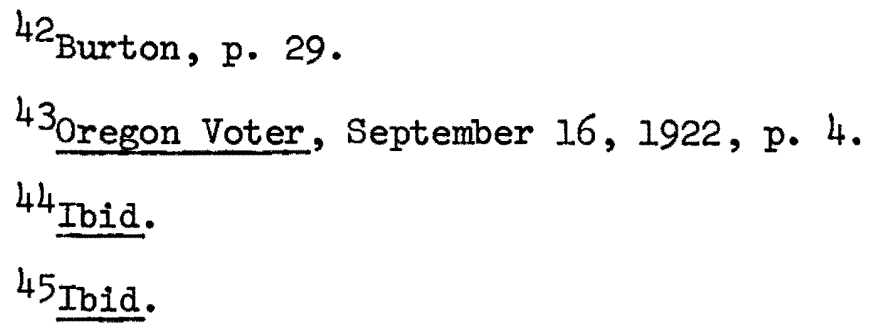


Gifford had vetoed the idea of Klan support for an independent for governor, negotiations were opened with both Pierce and Hall early in September. ${ }^{46}$ The probable reason for this action was to force Plerce to come out strongly for $\mathrm{Klan}$-backed measures to receive Klan support. (Hall apparently did not realize he was thus being "used" to force Pierce into a more acceptable position for Klansmen.)

Pierce's great fear was that the Compulsory School Act would be defeated. According to E. A. Koen of the Dallas Observer, Pierce felt that the initiative would be defeated by one hundred thousand votes, and that his support of it would cost him the election by fifty thousand. 47 Koen was exaggerating; while Pierce did fear the defeat of the bill, he was certainly politically knowledgeable enough not to make such a drastic error in judgment.

Had Hall not declared as an independent, Walter Pierce could have enjoyed Klan and Federation of Patriotic Societies support without opening his mouth, for the alternative of supporting Ben OIcott was so unpalatable that in a two-way race, their support would have gone easily to Pierce. Hall's re-entrance, however, forced Pierce to show more publically his support for issues supported by the $\mathrm{Klan}$. In one of the ironies of politics, Charles $\mathrm{Hall}$ then withdrew as a candidate after assessing his dismal chances.

${ }^{46}$ Tbid.

47 Oregon Voter, September 16, 1922, p. 5. 
The Oregonian of September 14 noted that Pierce's timely support of the Compulsory School Act seemed politically motivated. Pierce was apparently damned both by the bill's opponents, since he supported it, and by its proponents, who felt that his support was political. 48 (The Oregonian was not in favor of the Act.)

The concern, then, that swung those forty thousand disputed votes to Pierce was the growing realization that Hall was condemned to Iose. Even before his withdrawal from the race, the Kamath Falls Herald struck out at Hall's bolt of the party. The Dalles Chronicle accused Hall of not being "a good sport." The Bend Bulletin called him "the grouch candidate." 49 If a Klan-backed candidate was to win the governorship of 1922, Pierce was the logical choice.

Interestingly enough, however, the Oregon Voter from April 22 , 1922, through the November general election did not record one word of Olcott's on the subject of the Compulsory School Act. Olcott spoke only in the most general terms opposing the unwholesome influence of secret societies in Oregon politics. Though silent on the issue of the Compulsory School Act, there was no doubt after his May Proclamation of Olcott's unswerving hostility to the Klan itself. Thus, in the minds of many Oregonians, he became a symbol of both anti-KIan and anti-Compulsory School Act politics.

${ }^{48}$ Oregonian, September 14, 1922.

${ }^{49} \mathrm{AII}$ quotations from the Oregon Voter, September 2, 1922 , pp. 13, 19, 3i. 
The end came not as a surprise; rather, it confirmed the realization that Oregon politics in 1922 had taken a tone of religious bigotry and savagery heretofore unknown. Walter Pierce defeated Ben Olcott by a tally of 133,969 to $99,164.50$ As a final blow to the forces of tolerance, the Compulsory School Act also passed.

50 Onstine, p. 88 . 
CHAPTER III.

THE PUBLISHED WAR

The amount of propaganda published concerning the passage of the Compulsory School Act was both astounding and disappointing. The advertisements and pamphlets used were widely circulated; the role of the state's leading newspapers cast a more timid shadow on the issue. As noted in the nationally published Literary Digest, only two newspapers in the state openly opposed the measure while none supported it. ${ }^{1}$ The Oregonian in the days immediately preceding the election did discuss the Compulsory School Act in some detail; however, a ringing denunciation of the measure equivalent to the outrage of George Putnam in the Salem Capital Journal was not found on its pages.

Propaganda for the bill found more aid in the Klan-sponsored publications. Outstanding in this category was George Estes' forty-page work entitled The Old Cedar School. Arguing vehemently for Initiative 39, as the Compulsory School Act was also known, The 0ld Cedar School was a combination of propaganda techniques from nostalgia to humor.

I"Klan Victories in Oregon" (anon. article), Literary Digest, LXXV (November 25, 1922), p. 12. 
Luther I. Powell, the publisher of The Old Cedar School and "King Kleagle, Pacific Domain, Knights of the Ku Klux Klan," came the closest to any sort of rational argument for the Compulsory School Act. 2 Powell, writing in the Introduction, saw the passage of the bill as necessary to the preservation of the government. "A government found on the Will (sic) of the people will preserve their liberties in exact proportion to their understanding of its principles and no more. " ${ }^{3}$ (The emphasis was Powell's.) To Powell, public schools were the vehicle used by society to understand these crucial governmental principles. Thus, anyone who did not attend public schools was weakening the freedoms of all by his ignorance. Powell did not consider the possibility that study of these principles could be required even in parochial schools.

Powell did not see the Compulsory School Act as a limitation on religious freedom. "Privately, anything desired might be taught, including all religions or no religion." 4 This statement considered by itself would seem to indicate that Powell was not opposed to a. flourishing and vigorous program of religious education for all groups, regardless of belief. However, in the next paragraph Powell

2 George Estes, The Old Cedar School (Seattle, 1923) p. 5. ${ }^{3}$ Ibid.

${ }^{4}$ Ibid., p. 6. 
toned down his support of private education beyond the public

school by noting:

Private schools are generally under various religious denominations, each endeavoring to increase its membership and power by shaping the mental development of the young . . . in the accomplishment of this purpose is the tendency to eat away and undermine the public school system.'

One must be cognizant of the fact that ninety-three percent

of the state's students were in overcrowded public schools. 6 Powell did not estimate exactly how many parochial and private students represented an undermining of Oregon's public school system, but seven percent when the public schools were already overcrowded would seem an innocuous figure.

One of the oft-heard criticisms of the bill, that it was in fact a form of religious persecution, was mentioned but not truly refuted by Powell. He cited the example of the polygamists in Utah being denied their form of plural marriage as another case mistakenly labelled "religious persecution." Hoping to prove his point by example alone, he never convinced the reader that the initiative was not religious persecution.

The body of The Old Cedar School has as its plot the story of a concerned father trying to convince his multi-religious offspring to send their children to public schools instead of parochial schools. Author George Estes used a strictly emotional appeal with a style

5 Ibid.

6regonian, October $31,1922$. 
that tried to capture the folksiness of a simple but wise old

Oregonian.

The argument for public schools was succinctly put:

An' now, Jim, you went an' you married a 'Piscopalyun, which is good as far's I know, an' you din't want to send your children to that old Cedar Schaol over there 'cause it ain't good enough for 'Piscopalyuns. It was good enuff for me an' your mother 'cause there's where we got acquainted afore we was married . . .

The appeal of The Old Cedar School was not without classconsciousness. For example, Estes criticized Oxford Tower, apparently a "Piscopalyun" private school with sharp class distinctions:

- . there's a hull lot of big bishops an' fellers that wear their collars and vests buttoned in the back an' wide flat rims to their hats an' eat good grub an' draw big salaries 8 an' you have to pay an awful price for the learning' . . 8

Seventh Day Adventists, also known as strong opponents of the Compulsory School Act, were handled in a similar fashion. One of the narrator's daughters wanted to send her children to the "Saturday Sanctuary" which was described as a place where ". . they'd be learnin' a hull lot $o^{\prime}$ stuff 'bout which day of the week you goin' to rest on, which seems to me a great deal more necessary to find out which day you're goin' to work on." 9

Methodists with Stanhope Hall and Roman Catholics with the Academy of St. Gregory's Holy Toe Nail were similarly dismissed as harmful to the welfare of the state.

TEstes, p. 13 .

$8_{\text {Ibid. }}$ p. 16.

9 Ibid., p. 17. 
Interestingly enough, the folksiness of the narrator was dropped when the son asked the father what can be learned from the public school. A flat statement, "The material progress of a country is the sure indication of its advancement," was tied to the accomplishments of the public schools in three paragraphs of fluent and grammatical English. 10

The Old Cedar School ended with Estes' vision of public education without the Compulsory School Act. Drained by the defection of all the religious groups and upper-class private school patrons, disaster would strike the public school:

God in Heaven, Jim, our Old Cedar School House, next in my heart to Mother's grave, was tumblin' to the ground, in flames, the crushed and shriveled form of old Silas Parker, its teacher for mor'n fifty year, lay dead with his snow-white head hangin' out of the open front door, his thin, bony old hand aholdin' tight to the bell rope, the swayin' bell pealing its final call, an' the burnin' flag in the tall spire, THE IAST TORCH OF IIBERTY FADIN' FROM THE WORID. 11 (The emphasis was Estes?.)

The Old Cedar School enjoyed at least substantial local success. of course, the crucial questions involving its circulation remain unanswerable, for we are unable to determine how many copies went to the already-convinced Klansmen and their allies, and how many copies were actually instrumental in converting nay to aye votes for the passage of the Act the following November.

${ }^{10}$ Ibia., pp. 30-31

II Ibia., p. 43. 
Although pamphleteering was enthusiastic, the record of the press in Oregon was mixed regarding the $\mathrm{Ku} K \mathrm{~K}$ ux $\mathrm{Kl}$ an and the Compulsory School Act. As Chalmers notes, ". . the press of Oregon said scareely a word--even on events which were widely reported and discussed outside of the state."12

One journalist who did stand out against the Klan and the Act was George Putnam, editor of the Capital Journal in Salem. Putnam was known as a fighting liberal, a reputation he had established in his years as a newspaperman in Medford. He had purchesed the Capital Journal in 1919, and by the spring of 1922 Putnam was embroiled in his attacks on the Klan. ${ }^{13}$

Certainly of all the papers in Oregon, the Capital Journal was the most outspoken in its opposition to the Klan. Indeed, Putnam early felt that he had taken the field alone, unaccompanied and unsupported by the more widely-read dailies of Portland. George Turnbull, Putnam's biographer and admirer, commented:

It was not in the Putnam temperament to be patient and wait for a break. Other editors were slower, and the Capital Journal man early expressed bitter disappointment with the attitude of other newspapers, particularly of the Portland press on this incipient invasion of the rights of free citizens in Oregon. ${ }^{14}$

Putnam's editorial of February 16, 1922 pointed out the deficiencies of the Portland press in dealing with the hooded phenomenon.

12David Chalmers, Hooded Americanism (Garden City, New York, 1965), p. 88.

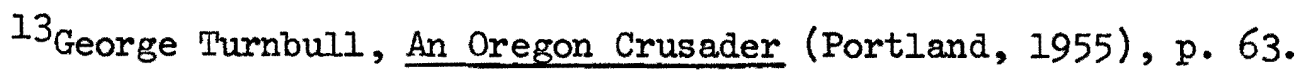
${ }^{14}$ Ibid., p. 66. 
Entitled "A Recreant Press," the editorial castigated both the lack of attack and the slipshod reporting methods of the Portland papers.

Putnam pressed his point regarding the Federation of Patriotic

Societies:

None of the newspapers have, however, at any time printed any real news concerning these organizations, who they were, or their representatives, what their principles and platform were, although every newspaper, as a matter of course, had the information. Nothing like this could be pulled off in the metropolis without all the newspapers knowing all about it. In failing to give the people the facts about this presumptous outfit, the Portland newspapers have not kept faith with the public. Intentionally, for reasons best known to themselves they have entered into a conspiracy of silence, either intimidated by the "patriots' or in sympathy with their aims and efforts ${ }_{i 5}$ In either case they have been recreant to journalistic ethics. 15

The Oregonian responded to these Putnam charges by noting that the names of the societies in question "are public property. There was no effort to disguise them in the school elections, nor is there now." 16 The Oregonian only listed the $K u K M l u x ~ K l$ an and the American Protective Association as part of the Federation, along with "other allied organizations." 17

Putnam, however, listed the following groups as "Real 100 percenters . . with very few exceptions":

Free and Accepted Masons, Knights of the Ku Klux Klan, Junior Order of the United American Mechanics, Guardians of Liberty, Sons and Daughters of Washington, Order of the Eastern Star, Daughters of America, Knights of Luther, Loyal Orange Institution, National Order of Pathfinders and Order of DeMolay. 18

${ }^{15}$ Ibid., p. 66-67.

16 Ibid., p. 67 .

17 Ibid.

${ }^{18}$ Ibid., p. 86. 
It was noted in Chapter I that Masonry was split on the issue of the Compulsory School Act. While some official pronouncements of Masonry decried the influence of the Klan, Putnam's estimation of the situation was unfortunately closer to the truth. While on the public level Masonry did strive to disassociate itself from the Klan, although not with a very convincing vigor in Oregon, privately many Masons at least supported $\mathrm{Kl}$ an measures if not taking an actual part in its activities themselves. This statement is understandably difficult to document, as membership lists of both societies are hard to verify for this or any era.

Putnam's stand on the Compulsory School Act was as forthright as his attack on the Portland press. Republican Senator Charles Hall had declared:

The public school is one of the fundamental factors in our system of government. I favor compulsory attendance in the primary grades. Teach pure Americanism to all pupils beginning at an early age. Continue to strengthen and build up this typical American institution. 19

The Capital Journal replied:

Stripped of its verbiage, this plank means the abolition of the parochial church and private school and the compulsory attendance of all children, regardless of parents' desire, at public school. For the first time religious and racial issues are raised in a state election in Oregon in an attempt to eliminate by sumptuary laws the bill of rights guaranteed by the Constitution. This is the idea of 'pure Americanism,' referred to by the apostles of intolerance. 20

${ }^{19}$ Ibid., p. 68.

20 Ibia. 
Putnam also hit at the increase in tax expenses for public schools. He was baffled by the stand of the Democratic candidate, Walter Pierce. Pierce came out in a breath for the Compulsory School Act and for the even-then overburdened property taxpayer who was footing a large portion of the public school bill. Putnam wondered editorially on September 16, 1922, "How can Mr. Pierce be in favor of reducing taxation in one paragraph and of increasing it unnecessarily in the next? He is reversing himself--standing on his head." 21

However, the great thrust of the Putnam attack against the Compulsory School Act remained on the ground of alienation of individual rights. For example, Turnbull cites this editorial dating from the end of June or early July, 1922:

This school bill, which violates the principles of the Bill of Rights, is not local in its origin but wished upon us by a distant grand lodge, a little group of non-resident secret society bosses, who admit that they cannot put such a measure over in their own states, and so interfere in Oregon institutions, and make Oregon really the fool of the family.

It bodes no good to the republic, this meddling of societies in politics and this interference of distant fanatics in our affairs. It can only create discord and strife. 22

This editorial was typical of Putnam's concern with the abuse of civil liberties coupled with his fear that the influence of secret societies on politics was at best an unwholesome and at worst a criminal activity.

$$
\begin{aligned}
& { }^{21} \text { Ibid., p. } 136 . \\
& { }^{22} \text { Ibid., p. } 98 .
\end{aligned}
$$


Following only the Capital Journal in the vigor of its attack, the Portland Telegram was the other outstanding anti-Klan voice in the state.

The Telegram began its campaign against the interference of the Klan by supporting 01cott in the Republican primary in May of 1922. On May 16 the front page carried a story under the headline, "Honest Americanism vs. Blind Fanaticism is Issue, Says 0lcott." A large picture of Olcott accompanied his statement of principles, part of which read:

I have never in any way, shape or form sought, asked for, bargained for or received the secret indorsement of any clan, society or organization. I say, with all sincerity, I would rather meet defeat in the primaries on Friday and be a free American than to serve another term in the governor's chair with the millstone of such an indorsement hanging about my neck. ${ }^{23}$

Directly beside this statement was the Telegram's editorial entitled "Choose the Best Men." For Governor, the Telegram supported the incumbent. "Gov. Ben Olcott is a progressive Republican, free and untrammeled, owning no allegiance to a machine, entitled to reelection on his record as governor." 24

The editorial page of the same Portland Telegram issue again hit at the Klan. "Un-American Methods" pointed out that the political activities of all secret societies were "inexcusable and un-American," including the Knights of Columbus. However, the Klan was the primary

\footnotetext{
23Portland Telegram, May 16, 1922.

${ }^{24}$ Portland Telegram, May 16, 1922.
} 
threat. "There has come into the midst of us suddenly without Invitation a secret masked order with professions of good will but with the methods of terrorism." 25

Just as the Oregon Journal struck out against Olcott in many front page stories, the Portland Telegram hounded Olcott's strongest challenger, Republican State Senator Charles Hall. On May 17 the Telegram printed on its front page a photostatic copy of a statement by the Coos and Curry Telephone Company showing that controlling interest in that firm was held by Pacific Telephone and Telegraph. Hall, one of the main owners of the Coos and Curry firm, had long been rumored to be a spokesman for the public utility interest in the state legislature. Accompanying the Hall story was the report that "Olcott Leaps to Front in Primary Race." The over-a.ll effect of the May 17 issue had to be damaging to Hall. 26

That Hall had strong public utility interests while remaining a favorite of the Federation of Patriotic Societies, a group rumored to oppose many utilities in Oregon, may seem incongruous. However, the utility issue was not as large in 1922 as it had been directly after the First World War, when the Federation was first organizing its political activities. That Hall supported the Compulsory School Act and anti-alien land ownership concepts was enough to secure for him Federation approval.

\footnotetext{
25 Ibid.

26 Portland Telegram, May 17, 1922.
} 
The summer of 1922 was sparse for reportage of Klan activity by the Portland Telegram. However, the newspaper again took up the battle before the November election. By supporting olcott strongly in his unsuccessful bid for the election and by just as strongly speaking out against the Compulsory School Act, the Telegram aligned itself diametrically opposite the $\mathrm{Ku} \mathrm{Klux} \mathrm{Klan}$ in Portland.

On October 31, 1922, the Telegram carried a page one editorial entitled "The Gist of the School Bill." This editorial hit the tax issue regarding the increase in public school attendance which would result if the parochial and private schools were outlawed.

No man with business intelligence needs to be told that the moving of 12,000 pupils from private to public school at an average public school teaching cost of $\$ 70$ per pupil (not including additional space accommadations) will mean an immense additional expense to the state-more, in fact, than Walter Pierce has given any indication of being able to save for the state under the most favorable circumstances. 27

The same issue of the Telegram printed a mock interview with Kaiser Wilhelm, billed as the EX. The Kaiser, not a popular figure in the United States after World War One, announced his support of both Pierce and the Compulsory School Act:

You may tell the world.. . that I am heartily in favor of the compulsory school bill in Oregon and that $I$ am sending a letter to Herr Walter Pierce, candidate for governor there and warm adrocate of the measure, giving both such support as my name may influence. 28

27 Portland Telegram, October 31, 1922.

28 Ibid. 
Three days later the Telegram featured another front page editorial addressed "To Oregon Mothers." The issue argued this time was that the Compulsory School Act deprived Oregon women of a God-given right to oversee the rearing of their children. "Is the majority rule to transcend a mother's right to direct the education of her children?" The Telegram's answer was a vehement "no." 29

On Monday, November 6 , the day before the general election, the Telegram published another in its controversial series which had been running for several days. The articles, entitled "I was a Klansman," purported to be the memoirs of an ex-Klan member. Filled with startling accusations of the conduct of the Klan in the Portland area, the series attracted wide attention. Now, one day before the election, the article dealt with the alleged political deal between Walter Pierce and the Klan:

After having recommended and roted in the Klan that it bring out Senator Hall as an independent candidate for governor, the Exalted Cyclops switched to Senator Plerce . . . When the Hall-Pierce switch was being engineered, the Exalted Cyclops declared in klonklave that Walter Pierce had pledged in return for the support of the klan that he would permit Gifford to dictate most of the political patronage of the state if elected. 30

By November 8 it was obvious to all observers in the state that both Pierce and the Compulsory School Act were victorious. In an editorial on page six, the Portland Telegram examined "The Revelations of Election:"

${ }^{29}$ Portland Telegram, November 3, 1922.

30 Portland Telegram, November 6, 1922. 
The apparent success of the so-called compulsory school bill is indeed a misfortune. It may not be called a tragedy until it shall be known whether the common sense of the people of Oregon, Protestant and Catholic, is to be depended upon between elections to smooth out the mistakes made in the heat of a political campaign... . In the fight against this bill the Telegram is confident that it was absolutely right in its stand. We are sure time will justify the position we have taken. . 31

If the Capital Journal and the Portland Telegram were the most outspoken major papers on the Compulsory School Act, the Oregonian had the most erudite examination of the situation. On Monday, October 30,1922 , the Oregonian began a series of editorials entitled "Education and the State." These were, in effect, a discussion of the Compulsory School Act from various angles.

The first article of the series stated the over-riding issue that the Oregonian saw in the bill. The question was "state authority versus parental authority" over the child. That the public schools were the domain of the government, and that the state was able to set requirements for all schools, public or private, were not argued by the Oregonian. Rather, "It remains only to see whether, to achieve this purpose (the integration of all children into the American system) it is necessary to revolutionize present systems, and to outlaw religious and private schools." The issue seemed to the Oregonian a matter of degree of control, not of moral right or wrong. 32

In the same article the paper had high words of praise for some of the proponents of the bill. "It is not necessary to say that so

${ }^{31}$ Portland Telegram, November 8, 1922.

32 Oregonian, October $30,1922$. 
patriotic, respectable and influential an organization as the Masons (Scottish Rite) would not sponsor any measure without the conscientious desire to promote the public welfare." 33

Finally, although the aims of the bill were not objectionable to the Oregonian, the newspaper doubted its constitutionality. "Let it be said here that the Oregonian, after studious and impartial Investigation, is convinced that the amendment is unconstitutional, and that the entire plan will fall behind any attack in the courts." 34 The article appearing on Tuesday, October 31, was merely a discussion of the history of free public education, both in western civilization and in this country alone. On Wednesday, however, the Oregonian harkened back to its line of argument presented in the October 30 article. Stating that "The right of the state to supervise parochial and private school is established by law and is not disputed by anyone," the Oregonian called for a stricter enforcement of existing laws rather than the passage of the new amendment. 35

"Education and the State's" fourth article, appearing November 2, 1922, suggested yet another drawback to the passage of the Compulsory School Act. The state's public schools were at that time overcrowded; what, the Oregonian wondered, would happen if the attendance figure suddenly rose by the number of parochial and private students who

33 Ibid.

${ }^{34}$ Ibid.

${ }^{35}$ Oregonian, November I, 1922. 
would then be required to attend public school? On Monday, October 30 , in the series' first article, the Oregonian had noted that ninetythree percent of the state's students were in public school. This figure indicated that the passage of the Compulsory School Act would increase attendance by seven percent. ${ }^{36}$ Putnam in the Capital Journal had earlier in the summer pointed out the conflicting stands of candidates who called for both a decrease of taxation and an increase of enrollment with the Compulsory School Act. 37

The final "Bducation and the State" article on Friday, November 3, discussed in greater detail the probable unconstitutionality of the measure. 38

The Oregonian's articles presented the issue in greater detail than did the other major papers in the state. The aims of the Act were discussed and even mildly applauded. Taxation increases were identified and decried. The constitutionality of the Act was examined and found wanting. The issue of religious liberty was not discussed. Besides the Portland Telegram and the Oregonian, Portland readers had a third choice. In all ways the position of the Oregon Journal was the most helpful to the Compulsory School Act's passage.

The Oregon Journal was staunchly behind Walter Pierce. However, it managed to support him for months without mentioning his advocacy

${ }^{36}$ Oregonian, October $30,1922$.

$37_{\text {Turnbull, p. } 93 .}$

38 Oregonian, November 3, 1922. 
of the Compulsory School Act. To the Oregon Journal the main issue was taxation, but the increase in taxes which would result from the Act's passage was never discussed on its pages.

The Oregon Journal did on rare occasions publish letters to the editor regarding the Compulsory School Act, even after its May declaration dismissing itself from the quarrel. An example of this policy was found on the editorial page of the Wednesday, November I, issue. Entitled "A Plea for Private Schools," C. F. Stevens' letter to the editor pointed out that the Compulsory School. Act would not insure an education to those whose parents have neglected them; rather, "it denied the right to have Christian school." 39

More noticeable than what appeared on the Oregon Journal's pages was what did not appear. Two Journal editorials in November discussed the importance of Pierce's election without ever mentioning the Compulsory School Act. On the same page as C. F. Stevens' letter, an editorial entitled "Radical?" defended Pierce's extreme positions by citing Washington, Iincoln, Robert FuIton and Edison as men who had also been called radicals. The Journal hit its favorite theme in its support of Pierce, that of the promised reduction of taxes. Never in the editorial, however, was the issue of compulsory public school attendance discussed. 40

39 Oregon Journal, November 1, 1922. 40 Ibid. 

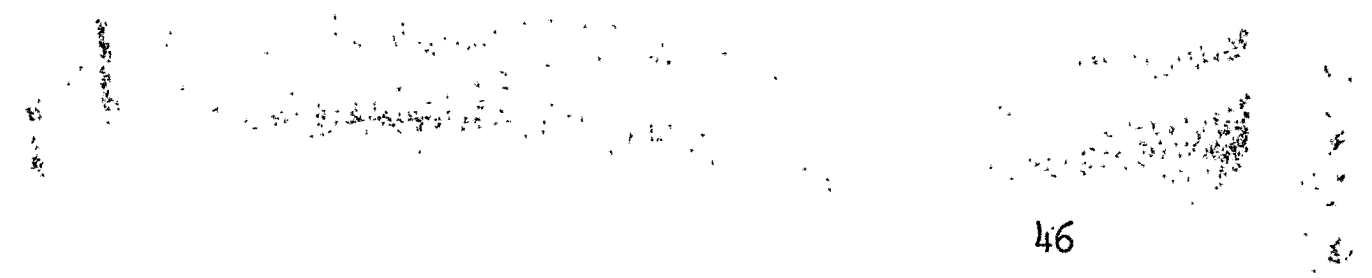

Two days later, the Oregon Journal again defended Pierce in an editorial entitled "The Can't Song." Once again, no mention was made of the school issue. 41

In other sections of the state, the tenor of editorials was similar. The Bend Bulletin, like the Oregonian, came out against the Compulsory School Act on financial grounds; $\$ 750,000$ would be added to the school bill of Bend tax-payers if the act were to pass. 42 Iikewise, the Corvallis Gazette-Times was against both the Ku Klus Klan and the Compulsory School Act. Of the Klan it noted:

The Klan has done nothing but stir up strife, and large differences of opinion in matters the discussion of which have always wrought the preatest hates and the most disastrous consequences in history. 43

The Gazette-Times also hit at the crucial aspect of tax increases which would be brought about by the bill's passage. 44

The Corvallis daily was not, however, liberal in its religious attitudes. Witness its reaction to Catholicism:

The Gazette-Times wants to see Catholicism wiped off the map insofar as the church is dominated by the Pope or any other group on the other side of the water. 45

On the whole Oregon's Iiterary output regarding the Compulsory School Act was mixed. George Putnam attracted much attention with

4 Ibid.

42Bend Bulletin, September 14, 1922.

${ }^{43}$ Corvallis Gazette-Times, September 28, 1922.

${ }^{44}$ Corvallis Gazette-Times, October I, 1922.

${ }^{45}$ Corvallis Gazette-Times, October 14, 1922. 
his forthright editorials, as did the Portland Telegram. The Oregonian, the Bend Bulletin and the Corvallis Gazette-Times were cautious with the issue, and the Oregon Journal avoided it altogether. Finally, as The OId Cedar School richly illustrates, the Klan side of the story was not told with anything approaching journalistic evidence. On the basis of this survey of the Oregon published material regarding the Compulsory School Act, it is disheartening to consider that the people of Oregon went to the polls in November of 1922 after having been exposed to so little clear discussion of the problem. 
THE COURT BATTLE OVER THE COMPULSORY SCHOOL ACT

Most observers in the state agreed that the passage of the Compulsory School Act at the polls of Oregon on November 7, 1922, was no assurance that the law would actually take effect. Even the previous summer newspapers throughout the state openly discussed the Act's as yet unchallenged constitutionality. Its approval by the voters of Oregon simply made a court battle inevitable. An advertisement in the November 1 issue of the Oregon Journal had quoted

A. E. Winship, the editor of the Journal of Education, as stating,

"We are sure the proposed legislation is unconstitutional." I The Oregonian's "Education and the State" editorials also openly questioned the constitutionality of the Compulsory School Act. ${ }^{2}$

These questions did not affect the Act's passage. As the Corvallis Gazette-Times noted:

The measure will carry with a whoop and if they (Iutherans) have any thought of spending good money to fight it in the campaign, let them instead husband their resources for, undoubtedIy it will take action by the supreme court to decide whether or not such a measure is legal. 3

${ }^{1}$ Advertisement in the Oregon Journal, November 1, 1922, paid for by the Non-Sectarian and Private Schools Committee.

${ }^{2}$ Oregonian, November 3, 1922.

3 Corvallis Gazette-Times, July 15, 1922. 
The two definitive cases against the Act were filed in United States District Court for the District of Oregon on January 15, 1924. Hill Military Academy, a Corporation, Plaintiff, V. Walter M. Pierce, as Governor of the State of Oregon, et al. and a parallel case filed by the Society of Sister of the Holy Names of Jesus and Mary took the legal initiative against the Act.

Hill Military Academy was represented by John C. Veatch, Attorney. His primary thrust of argument was the legality of Hill Military Academy's corporation, the propriety of its profits and the altogether destructive force of the Compulsory School Act on both.

That the net income derived by plaintiff from conducting said school is but a small percentage of said gross income and said school cannot be conducted at a profit with an average number of less than one hundred (100) students in attendance. 5

The Compulsory School Act was not to take effect until September of 1926. But the very passage of the Act had concerned the Academy's parents to the point that some were removing their children. The resultant financial harm was one of Veatch's strongest points in his argument.

That said pretended law is void and violates and contravenes the Constitution of the United States and more particularly Section 10 of Article 1 of the Constitution of the United States, and Section 1 of Article XIV of the amendments to

${ }^{4}$ Ancient Order of Hibernians, publishers. The Oregon School Fight (Portland, 1924), p. 28. (Note: This reference contains the transcripts of the school cases as argued in court, plus the decisions of the District and Supreme Court.)

5 Ibid., p. 26. 
the Constitution of the United States in that it deprives plaintiff of its property: without due process of law, denied to plaintiff the equal protection of the laws and impairs the obligations of plaintiff's contracts. 6

As evidence of the actual harm done by the passage of the bill, whether in effect or not, Veatch stated:

plaintiff's said business is now being destroyed and rendered valueless and plaintiff is now being deprived of its property rights therein; and plaintiff's said property is being depreciated in value and large percentage thereof rendered wholly valueless. 7

The attorneys for the Society of Sisters, J. P. Kavanaugh, Frank J. Lonergan, and Dan J. Malarkey, also first established the corporate right of the Society. Next, the dependency of the entire grade-school to junior college system on a healthy grade-school enrollment in the Society's buildings was used to establish real harm done by the Compulsory School Act. "And if said grade schools should be discontinued the patronage of said high schools and junior colleges would be materially reduced and impaired." 8

The attorneys for the Society also voiced a number of legal concerns about the Compulsory School Act. On these concerns they successfully based their case. The Compulsory School Act, according to Kavanaugh, Lonergan, and Malarkey, denied due process of law to the Society in the deprivation of property; it denied parental control over the child; it impaired the obligation of the Society's

$6_{\text {Ibid. , p. } 28 .}$

TIbid.

${ }^{8}$ Ibid., p. 37. 
contracts; it interfered with the "free exercise and enjoyment of religious opinions;" 1 it abridged the privileges and immunities of citizens of the United States by denying their right in Oregon to use parochial schools; and it gave the County School Superintendent "unlimited power and authority." 10 Some sociological evidence was also presented by the attorneys, the thrust of this being the number of parochial school students who would be forced into the public school system. 11

Attorneys McCammant and Thompson, speaking for the defense, hit hard the fact that on the day of the arguments, January 15, 1924, the Compulsory School Act was not in effect, nor would it be until September of 1926. "We have found no case in the books where the Court had passed on the constitutionality of a statute before the statute had become effective." 12

Veatch responded to this argument by noting that:

The bill (Hill's complaint) specifically states that at the present time students are being withdrawn from that school and that parents are refusing to enter into contracts with the plaintiff to enter other students in the school by reason of the existence of this law. ${ }^{13}$

In other words, although the effective date of the law was delayed, the damage was present and real.

9Ibid., p. 41.

${ }^{10}$ Ibid., pp. 40-42.

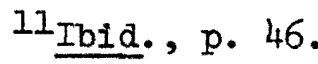

${ }^{12}$ Ibid., p. 56.

${ }^{13}$ Ibid., p. 65. 
McCammant, handling the burden of the state's arguments, also questioned the standing of the two corporations. While they discussed the issue of parental rights, the corporations were not parents and thus did not have standing to complain on those grounds. McCammant did not discuss the property damage claimed by the corporations, except to note that the contracts under which they were operating expired well before the law even took effect. ${ }^{14}$

The decision of the three judges, William B. Gilbert, Charles E. Wolverton, and Robert S. Bean, was announced March 31, 1924. Judge Wolverton, speaking for the three in unanimity, stated:

It can scarcely be contended that the complaintants' right to carry on their schools, whether parochial or private, is not a property right, and the right of parents and guardians to send their children and wards to such schools as they may desire, if not in conflict with lawful requirements, is a privilege they are inherently entitled to enjoy. 15

Wolverton agreed with the Society of Sister and Hill Military Academy that although the effective date of the Act was "somewhat remote," the damage being done was immediate and real. 16

Wolverton pointed to the need for a balance between the powers of a state to legislate for the good of society in general and the rights of the individual to maintain as much personal freedom as possible.

14 Ibia., p. 63.

I5 Ibid., p. 136.

16 Ibid., p. 137. 
The real test is, "Has the state through its legislative functions, the power, under the guise of police regulation, to deprive parochial and private school organizations of the liberty and right to carry on their schools for teaching in the grammar grades?"17

In conclusion, Wolverton demonstrated that these rights were protected by the Fourteenth Amendment of the Constitution of the United States.

Pierce and his co-defendants immediately appealed the case to the United States Supreme Court.

Pierce v. Society of Sisters of the Holy Names of Jesus and Mary; Same v. Hill Military Academy was argued before the Court on March 16 and $17,1925.18$ The decision was handed down the following June. On the 25th of that month, Mr. Justice McReynolds, speaking for the Court, declared the Compulsory School Act unconstitutional. The tenor of McReynolds' entire opinion is oriented toward a preservation of property and parental rights; nowhere is religious freedom discussed. McReynolds began his opinion by establishing that "without a doubt enforcement of the statute would seriously impair, perhaps destroy, the profitable features of the appellees' business and greatly diminish the value of their property." 19

The Society, McReynolds acknowledged, argued that the Act deprived parents and children of the right to choose schools appropriate to their religious beliefs and deprived schools and their

17 Ibid., p. 141.

18 Pierce v. Society of Sisters (286 US 510)

${ }^{19}$ Ibid., p. 572. 
employees of the right to follow a legitimate profession. 20 The situation appeared to McReynolds much the same for the Hill Military Academy. The Academy experienced the same drop in attendance and profit as did the Society after the state and county officials had declared the election valid. 21

McReynolds observed that the schools were not challenging the concept of partial state regulation of private and public schools:

No question is raised concerning the power of the state reasonably, to regulate all schools, to inspect, supervise and examine them, their teachers and pupils; to require that all children of proper age attend some school; that teachers be of good moral character and patriotic disposition; that certain studies plainly essential to good citizenship must be taught; and that nothing be taught which is manifestly inimical to the public welfare. 22

McReynolds continued that the business of the Society and the Academy was "Iong regarded as useful and meritorious," and that this business would be lost if the Compulsory School Act were enforced. 23 Therefore, the Opinion of the Court held that it was "plain" that the Act "unreasonably interferes" with the rights of both parents and children to seek an acceptable education and of the Society and the Academy to run legitimate businesses. 24 This marked

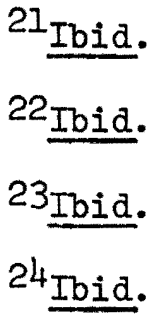


the first discussion by McReynold of the rights of children and parents to take part in educational decisions regarding the child's future;

The child is not the mere creature of the state; those who nurture him and direct his destiny have the right, coupled with the high duty, to recognize and prepare him for additional obligations. 25

Before ending the Opinion of the Court, McReynolds dispatched one last legal provision. Although the Compulsory School Act was still legally not yet in effect, the damage done to the corporations was immediate and real; therefore, their requests for an injunction against a law not yet in effect and a ruling on the same were legitimate. 26

It is necessary to recall that corporations were suing for the infunction and ruling in this case. Otherwise, one would wonder at lack of a statement regarding religious freedom. Parental rights were discussed by the decision to some extent, regardless of McCammant's earlier claim that the corporations had no standing to introduce these concerns into their arguments.

Although the civil libertarian recognizes a lack of discussion about the First Amendment's abridgement by the Compulsory School Act, the practical eye will discern wisdom in the approach used by the schools. Indeed, one feels that a property rights orientation would be much more welcome in the Supreme Court of the 1920!s than would a civil libertarian's approach. One must remember that fifteen

25 Ibid.

26 Ibia. 
years after the Supreme Court defended the property rights of private and parochial schools, it was not yet willing to allow religious sects a minimal freedom within public schools. Walter Gobitis, a member of the Jehovah's Witnesses, was told by the Supreme Court that "The mere possession of religious convictions which contradict the relevent concerns of a political society does not relieve the citizen from the discharge of political responsibilities." 27 The Gobitis case of course reflects other concerns, especially problems centering on the separation of church and state. This issue did not arise to any degree in the Pierce case. Thus, the issue first raised by Oregon voters in November of 1922 was laid to rest by the United States Supreme Court three years later. The Compulsory School Act was declared unconstitutional and became an interesting footnote to a significant period of Oregon's history.

27Minersville School District $\mathrm{v}$ Gobitis ( 310 US 586) 


\section{CHAPTER V}

\section{CONCLUSION}

The Ku KIux Klan, the Compulsory School Act and the gubernatorial race all serve to make 1922 an unique year in Oregon politicsThat the Klan should flourish in a state as outwardly progressive as Oregon seems on the surface a contradiction; but when the state in 1922 is analyzed its fertility for Klan activity becomes apparent. This activity was aimed primarily at the great question of the role and scope of public school. Oregon was not alone in feeling this agitation, but it was alone in witnessing "the only genuinely $\mathrm{K}$ lan-inspired measure" to be enrolled as a state law anywhere. ${ }^{I}$ That the law was struck down in the courts in defense of corporate and parental interests does not erase the single, unavoidable fact of the matter-the people of Oregon passed a law that was both Klanbacked and most harmful to individual liberty.

The battle for the Compulsory School Act was hard-fought and bitter. A frequently quoted statement of the New York Times noted that, "The School Bill was the most upsetting factor in the history of Oregon since the agitation over slavery."2 This deep feeling carried

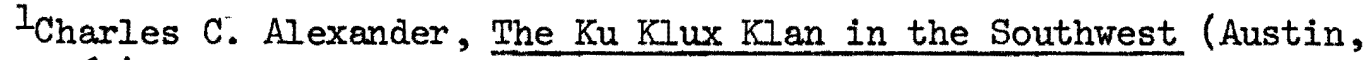
Texas, 1965), p. 111.

2The New York Times, November 9, 1922. 
over into "the bitterest and closest political campaign in Oregon's history," the struggle for the Republican gubernatorial nomination in the spring of $1922 .^{3}$

The general election saw a rerun of the intensity of emotion as the issue of $\mathrm{Kl}$ an support for Plerce became critical. That that support was keyed to the timely announcement of his support for the Compulsory School Act has been demonstrated; Pierce in later years was faced with charges of being a Klansman himself. It is beside the point to debate here that long-dead and impossible to establish fact. However, the Klan did at least aid Pierce in gaining the governorship. Charles C. Alexander in The Ku Klux Klan in the Southwest holds that, "In Oregon the Klan was responsible for electing a Democratic governor in a predominantly Republican state." 4

Robert E. Burton is in agreement on the contribution of the Klan to Pierce's successful bid:

After the election, the $\mathrm{Kl}$ an boasted that it was responsible for the election of Pierce to the governorship. Pierce later denied that he made an official alliance with the Klan and that he rewarded Klansmen with patronage, but it seems obvious that he received the votes of those motivated by racial and religious prejudice. 5

"The Ku Klux Klan in Politics" (anon. article), Literary Digest, LXXIII (June 10, 1922), p. 15.

${ }^{4}$ Alexander, p. 127 .

5Robert E. Burton, Democrats of Oregon: The Pattern of Minority Politics, 1900-1956 (Eugene, 1970), p. 49. 
Finally, Chalmers notes that Oregon was one of ten states where governors were elected with Klan aid. ${ }^{6}$

The divisive fight at the polling booth was only one instance of harm to Oregon. Almost as critical was the failure of most major newspapers to speak forthrightly on the issue of the Compulsory School Act. The Portland Telegram and Salem's Capital Journal stand as notable exceptions; the position of the Oregon Journal is quite at the other end of the spectrum.

Likewise, the legal fight to stop the Compulsory School Act was successful, but one feels the wrong reasons won the war. There was no outcry at the lack of individual religious liberty in the law; yet the principle that private and parochial schools could not be deprived of their property without due process of law was carefully guarded. Mr. Justice McReynolds also spoke convincingly of the rights of parents and children in determining at least part of the educational scheme of children.

Altogether, the year 1922 must have seemed confusing to many Oregonians. Politics in that year were tinged with deep shades of emotion; religion became an issue in a state in which two years before the Ku KIux Klan did not even exist. The changes were baffling in their rapidity; within a three year span the nation's only antiparocial and private school law was introduced, passed and declared

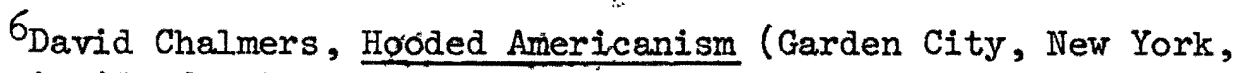
1965), inside front cover. 
unconstitutional. Likewise, a Democratic governor was elected in a Republican state.

Precisely because of these unusual events must one take note of Oregon politics in I922, when the Ku Klux Klan, the governor's race and the Compulsory School Act all wove a net of emotion for Oregonians. 
A LIST OF SELECTED REFERENCES

Alexander, Charles C. The Ku Klux Klan in the Southwest. Austin, 1965.

Ancient Order of Hibernians of Oregon. The Oregon School Fight, a True History. Portland, 1924.

The Bend Bulletin.

Burton, Robert E. Democrats of Oregon: The Pattern of Minority Politics 1900-1956. Eugene, 1970 .

Carey, Henry A., Jr. "The Klan in Oregon when Catholics in Oregon saved parochial schools for the United States," Catholic Contributions to Oregon History. St. Benedict, Oregon, 1959.

Chalmers, David. Hooded Americanism. Garden City, New York, 1946.

The Corvallis Gazette-Times.

Estes, George. The 01d Cedar School. Seattle, 1923.

Frost, Stanley. The Challenge of the Klan. New York, 1925, 1969.

Holsinger, M. Paul. "The Oregon School Bill Controversy," Pacific Historical Review, XXXVI, Berkeley, October, 1968.

Jackson, Kenneth. The Ku Klux Klan in the City, 1915-1930. New York, 1967.

"Klan Victories in Oregon and Texas." Anon. article, Iiterary Digest, IXXV (November 25, 1922.)

"The Ku Klux Klan in Politics." Anon. article, Literary Digest, LXXIV (June 10, 1922.)

Lipset, Seymour Martin and Raab, Earl. The Politics of Unreason: Right-Wing Extremism in America 1790-1970. New York, 1970.

Lowe, David. Ku Klux Klan: The Invisible Empire. New York, 1967.

Mecklin, John Moffatt. The Ku Klux Klan: A Study of the American Mind. New York, 1924. 
Minersville School District $v$. Gobitis. 310 US 586.

Onstine, Burton. Oregon Votes. Portland, 1973.

The Oregonian.

The Oregon Journal.

The Oregon Voter.

Pierce v. the Society of Sisters of the Holy Names of Jesus and Mary. 268 US 510 .

The Portland Telegram.

Randel, William Pierce. The Ku Klux Klan: A Century of Infamy. New York, 1965.

Roberts, Waldo. "The Ku Kluxing of Oregon." Outlook, 133 (1923) pp. 490-91.

Saalfeld, Lawrence. "Forces of Prejudice in Oregon, 1920-1925." Unpub. Master's Thesis done at the Catholic University of America, 1950.

The Salem Capital Journal.

Turnbull, George. An Oregon Crusader. Portland, 1955.

"Wiping Out Oregon's School Law." Anon. article, Literary Digest, LXXXI (April 26, 1924.) 